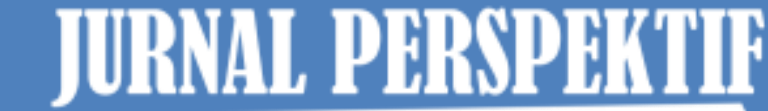 Junnal Kälian Sosioloni dan Pendidikan}

Jurnal Perspektif: Jurnal Kajian Sosiologi dan Pendidikan Vol. 4 No. 4 Tahun 2021

http://perspektif.ppj.unp.ac.id

Email: perspektif@ppj.unp.ac.id

ISSN: 2622-1748 (Online), 2684-902X (Print)

DOI: http://dx.doi.org/10.24036/perspektif.v4i4.486

\title{
Representasi Diri Melalui Instagram oleh Mahasiswa Jurusan Sosiologi Universitas Negeri Padang
}

\author{
Aulia Alqiva', Mohammad Isa Gautama ${ }^{2}$ \\ 1,2 Universitas Negeri Padang \\ Email: auliaalqiva1999@gmail.com, migatama@ fis.unp.ac.id
}

\begin{abstract}
Abstrak
Permasalahan yang diangkat pada penelitian ini adalah mengenai apa yang ingin mahasiswa Jurusan Sosiologi Universitas Negeri Padang tampilkan pada panggung Instagram untuk mewujudkan perilaku representasi dirinya. Metode penelitian yang digunakan adalah metode deskriptif kualitatif. Prosedur dalam pengambilan sampel menggunakan teknik purposive sampling, dengan teknik pengumpulan data wawancara, dokumentasi dan observasi. Mahasiswa melakukan hal-hal tertentu demi mencapai representasi diri yang diinginkannya yakni melalui usaha representasi dengan menjadikan Selebgram, Sosialita dan Motivator sebagai basis pedoman atau standar perilaku representasi diri oleh mahasiswa Jurusan Sosiologi Universitas Negeri Padang. Mahasiswa yang mempresentasikan dirinya seperti Selebgram dengan mengunggah sesuatu yang mengikuti trend agar eksis di dunia maya. Kemudian ciri-ciri mahasiwa yang merepresentasikan dirinya seperti Sosialita adalah dengan mengenakan barang-barang branded dan pergi ke tempat yang instagramable. Sedangkan ciri mahasiswa yang mempresentasikan diri seperti Motivator yakni dengan mengunggah kalimat-kalimat bijak. Hal yang dilakukan mahasiswa tersebut sesuai dengan Teori Dramaturgi yang dikemukakan oleh Erving Goffman. Mahasiswa memerankan peran sesuai peran yang dipilihnya di panggung depan, panggung depan dalam hal ini adalah dunia maya media sosial Instagram dimana mahasiswa membangun representasi dirinya. Tujuan mahasiswa bermain peran di panggung depan adalah untuk memberikan kesan tertentu terhadap orang lain sesuai dengan peran yang dimainkan. Supaya dapat memainkan perannya di panggung depan dengan baik, mahasiswa mempersiapkan segala sesuatunya di panggung belakang. Panggung belakang tersebut adalah kehidupan nyata mahasiswa yang tidak ditampakkan di dunia maya. Selain itu panggung belakang juga merupakan tempat untuk menyembunyikan hal-hal tertentu yang dapat merusak representasi diri dari mahasiswa.
\end{abstract}

Kata Kunci: Instagram, Mahasiswa, Representasi Diri

Abstract
The problem raised in this study is about what students of the Department of Sociology at Padang State University want to display on the Instagram stage to realize their self-representation behavior. The research method used is descriptive qualitative method. The procedure for taking samples using purposive sampling technique, with data collection techniques interview, documentation and observation. Students do certain things to achieve the self-representation they want, namely through representation efforts by making Celebrities, Socialites and Motivators as the basis for guidelines or standards of self-representation behavior by students of the Department of Sociology, Padang State University. Students who present themselves like Selebgram by uploading something that follows the trend to exist in cyberspace. Then the characteristics of students who represent themselves like Socialites are by wearing branded goods and going to instagramable places. While the characteristics of students who present themselves are like motivators, namely by uploading wise sentences. What the student did was in accordance with the Dramaturgy Theory proposed by Erving Goffman. Students play roles according to their chosen roles on the front stage, the front stage in this case is the virtual world of Instagram social media where students build their own representation. The purpose of students playing a role on the front stage is to build an impression in the minds of others according to the role they play. In order to play their role on the 
front stage well, students prepare everything on the back stage. The backstage is a student's real life that is not shown in cyberspace. In addition, the back stage is also a place to hide certain things that can damage the self-representation of students.

Keywords: Instagram, Self Representation, Student

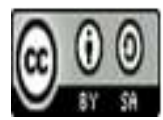

\begin{tabular}{l|l|l} 
Received: August 10, 2021 & Revised: September 28, 2021 & Available Online: Oktober 27, 2021
\end{tabular}

\section{Pendahuluan}

Perkembangan teknologi dan komunikasi kini telah merubah pola interaksi antar individu, saat ini internet menjadi sebuah ruang digital yang menciptakan ruang kultural. Tidak dapat dipungkiri bahwa dengan keberadaan internet memberikan banyak kemudahan kepada penggunanya. Seiring dengan perkembangan zaman cara manusia untuk saling berkomunikasi juga terus berkembang mengikuti perkembangan teknologi, sehingga dapat menghadirkan beragam aplikasi pesan antar (instant messaging) dan juga beragam model Web 2.0 sebagai sarana komunikasi antar pengguna internet. Era ini disebut juga sebagai era media baru atau new media. (Arlian, 2015)

Saat ini internet tidak hanya digunakan untuk bekerja dan keperluan pendidikan, tetapi juga semakin dekat dengan kebutuhan sehari-hari, seperti media sosial yang memiliki keberagam. Setidaknya ada puluhan media sosial yang tersebar di seluruh penjuru internet, namun tidak semua media sosial mendapatkan perhatian yang sebanding. Ada beberapa media sosial yang lebih unggul dibandingkan dengan yang lainnya. Tentunya dengan media sosial ini, masing-masing individu memiliki kehidupan di dunia nyata dan dunia maya. Kehidupan di dua dunia ini telah berlangsung sejak munculnya media sosial. Berbagai macam media sosial menjadi habitat bagi para pengguna internet untuk berinteraksi dan berkembang di ranah digital. Media sosial sendiri merupakan wadah yang memungkinkan penggunanya untuk bisa mengungkapkan segala ekspresi yang sedang dirasakan pada saat itu. Salah satu media sosial yang populer beberapa tahun belakangan adalah Instagram. Aplikasi intagram bisa diakses oleh pengguna dari berbagai kalangan, terlihat dari gambar grafik penggunaan media sosial berikut ini.

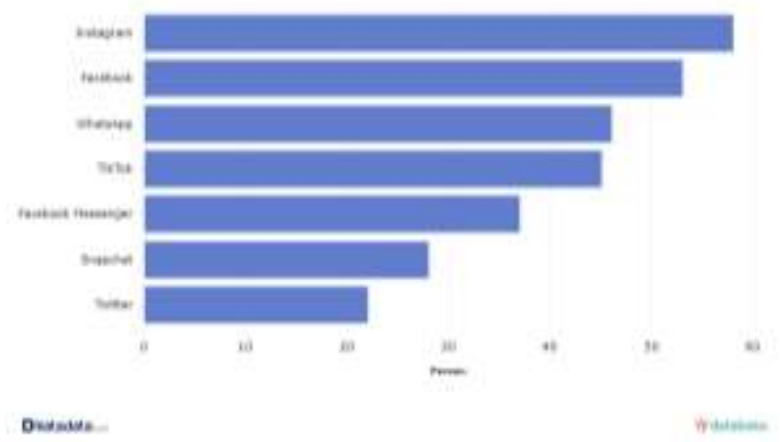

\section{Gambar 1. Grafik Penggunaan Media Sosial Setiap Hari (Kuartal I-2021) Di Indonesia}

Berdasarkan tabel di atas terlihat bahwa penggunaan Instagram di Indonesia mencapai 58\% banyaknya pengguna (Lidwina, 2021). Instagram merupakan sebuah aplikasi berbagi foto atau video yang memungkinkan pengguna mengambil foto, menerapkan filter digital dan membagikannya keberbagai layanan jejaring sosial termasuk milik Instagram sendiri. Instagram adalah layanan jejaring sosial berbasis fotografi, diresmikan pada tanggal 6 Oktober 2010 oleh Kevin Systrom dan Mike Krieger yang mampu menjaring 25 ribu 
pengguna di hari pertama. Instagram dianggap sebagai salah satu media yang paling fresh dan memiliki jumlah followers yang paling banyak diantara media sosial lainnya (Atmoko, 2012). Hal ini disebabkan karena Instagram lebih fokus dengan foto dan video yang berdurasi pendek, ditambah dengan fitur-fitur yang canggih dan dapat melihat dengan jelas artis lokal hingga mancanegara serta foto atau video apa saja yang diinginkan telah memiliki akun serta aktif di Instagram yang dapat dengan mudah untuk mengetahui tentang hal apa saja yang diinginkan.

Berdasarkan hasil penelitian yang telah dilakukan oleh Monavia (2021) jumlah pengguna Instagram di Indonesia hingga Juli 2021 sebesar 91,77 juta pengguna dengan pengguna terbesar dari kelompok usia 18 - 24 tahun yaitu 36,4\%. Saat ini instagram berada di urutan ketiga sebagai platform media sosial yang paling sering digunakan, setelah Youtube dan WhatsApp (Monavia, 2021). Instagram menjadi media sosial yang sangat populer di berbagai belahan dunia karena memungkinkan penggunanya untuk berbagi konten fotografi serta mengikuti kehidupan para pesohor favorit.

Alwisol menjelaskan bahwa memang kenyataannya, sesuai dengan teori motivasi manusia Abraham Maslow, dimana variasi kebutuhan manusia dipandang tersusun dalam bentuk hirarki atau berjenjang. Setiap jenjang kebutuhan dapat dipenuhi hanya kalau jenjang sebelumnya telah relatif terpuaskan. Pada kebutuhan dasar keempat yaitu kebutuhan harga diri (self esteem), apabila kebutuhan jenjang sebelumnya relatif terpuaskan, kekuatan motivasinya melemah, diganti motivasi harga diri. Ada dua jenis harga diri yaitu menghargai diri sendiri (self respect) dan mendapat penghargaan dari orang lain (respect from others) (Alwisol, 2010).

Kepuasan kebutuhan harga diri menimbulkan perasaan dan sikap percaya diri, diri berharga, diri mampu dan perasaan berguna dan penting di dunia. Hal ini dapat ditunjukkan bahwa manusia memiliki eksistensi diri ingin mengkomunikasikan dirinya bahwa dia ada.Dalam hubungannya dengan Instagram seseorang dapat mewujudkan representasi dirinya dengan mengunggah selfie atau video kegiatannya melalui instastory serta menambahkan filter lucu dan bagus, lalu membagikan foto di Instagram feed sebagai bentuk representasi diri dalam menggunakan aplikasi instagram tersebut (Alwisol, 2010).

Seiring berjalannya waktu, Instagram mulai berkembang yang pada awalnya hanya sebatas media untuk saling berkomunikasi kini telah menjadi salah satu media yang menyediakan berbagai informasi baik itu ilmu pengetahuan umum hingga sampai kepada kejadian yang sedang viral. Berkat Instagram yang semakin inovatif dalam hal fitur menyebabkan jumlah penggunanya terus bertambah hingga merambah ke ranah pendidikan yaitu para civitas akademik dalam hal ini adalah mahasiswa. Mahasiswa yang memiliki fungsi sebagai salah satu agen perubahan menggunakan Instagram sebagai wadah untuk berkarya dan berinovasi. Tetapi yang terjadi sekarang tidak sesuai berdasarkan fungsinya.

Berdasarkan hasil wawancara penulis dengan beberapa mahasiswa Jurusan Sosiologi Universitas Negeri Padang, kebanyakan dari mereka mengikuti fashion di Instagram agar terlihat tidak ketinggalan zaman. Dengan adanya Instagram juga banyak tempat-tempat yang bagus bermunculan kalau istilahnya Instagramable. Tak sedikit orang terutama para mahasiswa tak segan-segan mendatangi tempat tersebut untuk sekedar berfoto untuk mengisi feed instagram mereka. Hal tersebut dilakukan supaya mereka terlihat dimata para teman maupun followers bahwa mereka update mengenai apa yang lagi viral.

Lalu, mahasiswa Jurusan Sosiologi Universitas Negeri Padang ini membeli pakaian, tas branded, make up dan barang-barang yang bermerk lainnya untuk mengikuti trend agar mereka bisa share foto mereka di Instagram. Meski hanya untuk berpergian di dekat sekitas 
rumah atau kosan, mahasiswa ini harus touch up atau dandan terlebih dahulu agar terlihat rapi dan menarik untuk keperluan representasi diri, memperlihatkan gaya hidup mereka dan tidak lupa untuk membuat story Instagram. Manusia sebagai aktor yang kreatif mampu menciptakan berbagai hal, salah satunya adalah ruang interaksi dunia maya. Setiap individu mampu menampilkan karakter diri yang berbeda ketika berada di dunia maya dengan dunia nyata.

Kehadiran ruang publik yang ada di cyberspace ternyata malah merangsang tumbuhnya perilaku dan gaya hidup yang berbeda yaitu gaya hidup remaja urban yang lebih banyak di kendalikan oleh hasrat dan keinginan untuk terus membeli produk-produk atau barang-barang industri budaya terbaru daripada idealisme untuk memperjuangkan kepentingan dan perkembangan demokrasi. Kehadiran media sosial di kalangan mahasiswa kini membuat ruang privat seorang individu menjadi ruang publik. Terjadi pergeseran budaya di kalangan mahasiswa. Mahasiswa kini tidak segan-segan membagikan segala bentuk kegiatan yang bersifat pribadi ataupun tidak pribadi untuk di sampaikan kepada teman-temannya melalui akun media sosial Instagram membentuk representasi diri mereka (Sugihartati, 2014).

Dalam konsep Dramaturgi oleh Erving Goffman bahwa individu akan berlomba-lomba menampilkan dirinya sebaik mungkin. Goffman mengasumsikan bahwa ketika orang-orang berinteraksi, mereka ingin menyajikan suatu gambaran diri yang akan diterima orang lain. Menurut (Poloma, 2013) upaya ini disebut sebagai pengelolaan kesan (impression management), yaitu teknik yang digunakan aktor untuk memupuk kesan-kesan tertentu dalam situasi tertentu untuk mencapai tujuan tertentu. Berdasarkan fenomena serta pemaparan yang telah disampaikan berdasarkan permasalahan di atas maka penulis tertarik untuk melakukan penelitian dengan judul "Representasi Diri Melalui Instagram oleh Mahasiswa Jurusan Sosiologi Universitas Negeri Padang".

\section{Metode Penelitian}

Metode penelitian yang digunakan pada penelitian ini yaitu metode deskriptif kualitatif dengan teknik pengumpulan data wawancara, dokumentasi dan observasi. Alasan peneliti menggunakan metode penelitian deskriptif kualitatif adalah jenis penelitian ini berlandaskan pemahaman akan realitas sosial. Penelitian kualitatif berusaha memahami pembentukan di dalam diri seseorang. Melalui pendekatan deskriptif ini, diharapkan mendapatkan data hasil yang nantinya akan diinterprestasikan oleh peneliti, data tersebut merupakan yang ditemukan oleh peneliti dilapangan.

Adapun yang menjadi informan pada penelitian ini yaitu 10 mahasiswa Jurusan Sosiologi Universitas Negeri Padang. Informan tersebut adalah FH dengan jumlah followers (13.100) orang, HD dengan jumlah followers (10.800) orang, BNP dengan jumlah followers (5.886) orang, MPI dengan jumlah followers (4.017) orang, MA dengan jumlah followers (3.155) orang, CI dengan jumlah followers (2.480) orang, PIS dengan jumlah followers (2.179) orang, MCN dengan jumlah followers (1.823) orang, ARKN dengan jumlah followers (1.246) orang, OA dengan jumlah followers (1.178) orang. Pemilihan informan yang digunakan dalam penelitian ini didasarkan pada teknik purposive sampling, hal ini bertujuan agar informan dapat memberikan informasi yang dibutuhkan berkaitan dengan masalah yang diteliti. Ada pun alasan kesepuluh orang ini dijadikan informan adalah informan ini memiliki akun media sosial Intagram yang aktif, minimal postingan instastory dalam sehari 3 kali, dengan followers atau pengikut minimal 1000, agar dapat memudahkan peneliti dalam pengumpulan informasi terkait penelitian, karena setiap kegiatan unggahan foto ke instagram akan menunjukkan bentuk representasi diri mahasiswa tersebut. 


\section{Hasil dan Pembahasan}

\section{Representasi Diri dalam Media Sosial Intagram}

Media sosial Instagram merupakan media untuk berinteraksi tanpa harus bertatap muka, mempermudah komunikasi juga mengenal orang lain tanpa harus bertemu langsung, karena bisa dinilai dari apa yang orang tersebut publish. Walaupun belum tentu apa yang dipublish atau misal apa yang ditulis merepresentasikan karakter orang tersebut. Media sosial juga tidak jarang menjadi ajang promosi diri sekaligus menjadi private diary. Banyak orang yang tidak sekedar 'curhat' tapi juga kadang memberikan 'kode' lewat media sosial entah kepada orang yang siduka ataupun orang yang tidak disukai dan mungkin yang paling sering dilakukan ialah selfie dengan berbagai pose atau ekspresi membuat orang ingin mempublikasikannya apalagi jika jumlah like atau love yang didapat banyak, bukan tidak mungkin keesokan harinya ia akan menambah jumlah pose ataupun ekspresinya, karena akan membuatnya semakin eksis di dunia Instagram.

Menurut (Nasrullah, 2015) Riset yang dipublikasikan oleh Crowdtap, Ipsos MediaCT dan The Wall Street Journal pada tahun 2014 melibatkan 839 responden dari usia 16 hingga 36 tahun menunjukkan bahwa jumlah waktu yang dihabiskan khalayak untuk mengakses internet dan media sosial mencapai 6 jam 46 menit per hari, melebihi aktivitas untuk mengakses media tradisional. Hal tersebut menunjukkan bahwa masyarakat lebih gemar menggunakan media sosial daripada media tradisional seperti koran atau majalah. Hal itu dapat dilihat di sekitar kita, orang betah berlama-lama memaminkan smartphonenya untuk melihat media sosial yang ada pada smartphonenya seperti Intagram, Facebook, Twitter atau Youtube.

Melalui foto yang diunggah ke Instagram, dianggap dapat membangun citra dari sang pengguna karena foto dapat mewakili identitas diri seseorang. Hingga muncul sebuah istilah yakni Instagram Management berdasarkan fenomena yang sering terjadi di jagad dunia maya. Menurut (Atmoko, 2012) Instagram Management adalah sebuah tindakan menampilkan diri yang dilakukan oleh setiap individu untuk mencapai sebuah representasi diri yang diharapkan melalui Instagram. Seseorang akan mengunggah foto yang dapat membantunya membangun citra sebagaimana yang ia inginkan dalam Instagram. Kegiatan tersebut juga dapat dibilang sebagai representasi diri, dimana seseorang mempresentasikan dirinya kepada publik sebagaimana yang ia ingin tampilkan yang nantinya akan menumbuhkan citra tertentu dalam benak orang lain.

\section{Representasi Diri Mahasiswa Jurusan Sosiologi Universitas Negeri Padang di Instagram}

Seiring berkembangnya zaman, sumber informasi bisa berasal dari mana saja. Tak hanya dari media cetak atau televisi saja, bahkan kini informasi bisa di dapat melalui media sosial. Salah satunya yakni Instagram, melalui Instagram kita dapat mengetahui informasi baik itu dari dunia entertainment, berita, kejadian yang sedang viral dan bahkan mengenai politik, hal ini sesuai dengan pernyataan oleh OA informan peneliti yaitu:

“...Saya menggunakan Instagram untuk melihat fenomena yang sedang viral, lalu melihat berita yang terbaru, upload instastory atau foto feed Instagram..." (Wawancara, tanggal 12 Juni 2021).

Selain OA peneliti juga mewawancarai informan lain dengan inisial $\mathrm{FH}$ berikut pernyataannya: 
“...Saya menggunakan Instagram untuk mengikuti era globalisasi 4.0 yang berfokus pada teknologi digital. Jika tidak mengikuti perkembangan maka akan ketinggalan berita yang sedang viral dan informasi penting lainnya. Lalu, saya menggunakan Instastory Instagram untuk posting tentang perkembangan politik Indonesia karena saya selalu mengikuti polemik politik yang terjadi di negara kita ini..." (Wawancara, tanggal 12 Juni 2021).

Mahasiswa Jurusan Sosiologi Universitas Negeri Padang menggunakan Instagram untuk mencari dan memperoleh informasi mengenai apa yang sedang terjadi saat ini dan apa yang sedang hangat dibicarakan oleh masyarakat. Namun seiring berkembangnya zaman, penggunaan Instagram mulai bergeser dari awalnya sarana komunikasi dan berbagi, berubah menjadi media tempat orang melakukan representasi diri. Menurut (Gautama, 2017) di abad digital ini media daring menjadi salah satu instrumen pencitraan. Semua orang yang memiliki akses ke media daring berpotensi membentuk citra dirinya.

Instagram menyediakan fitur follow untuk penggunanya. Fitur tersebut adalah dimana kita dapat mengikuti akun seseorang sehingga kita dapat melihat foto, video dan Instastory seperti yang diunggah oleh orang itu. Followers tersebut bisa saja merupakan orang yang memang dikenal di dunia nyata atau bahkan merupakan orang yang tidak dikenal sama sekali di dunia nyata, hanya orang asing yang mengikuti atau following akun kita. Hal ini sesuai dengan pernyataan oleh HD mengenai seberapa pentingnya followers baginya yaitu:

“...Bagi saya followers Instagram itu sangat penting. Jika followers di Instagram kita sedikit maka dianggap orang yang tidak eksis di Instagram. Tetapi sebaliknya, jika jumlah followers kita banyak maka akan dianggap terkenal. Seperti contohnya saya memiliki followers yang banyak sudah seperti selebgram dan saya bisa membuka endorse..." (Wawancara, 13 Juni 2021).

Jumlah followers dianggap penting oleh mahasiswa Jurusan Sosiologi Universitas Negeri Padang, karena berdasarkan jumlah followers yang dimiliki dapat menentukan seberapa eksis orang tersebut di dalam dunia media sosial Instagram. Bagi sebagian orang, jumlah followers merupakan hal yang penting karena dari situlah dapat dilihat seberapa eksis kah seseorang dalam dunia media sosial, tak hanya Instagram saja tetapi hal tersebut juga berlaku untuk platform media sosial lainnya. Bahkan karena dianggap sangat penting, dapat membuat seseorang melakukan hal yang berbeda untuk mendapatkan followers. Yakni dengan membeli followers kepada penyedia jasa tersebut. Seseorang bisa mendapatkan followers dengan jumlah banyak secara cepat dengan cara memberi sejumlah rupiah kepada penyedia jasa tersebut. Semakin banyak rupiahnya, maka akan semakin banyak pula followers yang didapatkan. Bersamaan dengan bergesernya penggunaan media sosial yang awalnya untuk berkomunikasi dengan orang lain yang berada jauh dengan kita, kini media sosial menjadi tempat orang melakukan representasi diri. Seseorang yang memiliki ambisi tinggi untuk eksis di dalam lingkungannya dengan status sosial yang lebih tinggi dari status mereka sebenarnya.

Seseorang melakukan representasi diri namun image tersebut tidak ada pada dirinya, yang membuat dirinya menutup kehidupan pribadinya demi manjaga citra yang telah dibangun tersebut. Selain menginginkan eksistensi di dunia maya, seseorang yang melakukan representasi diri juga menginginkan pengakuan dari orang di sekelilingnya berdasarkan representasi diri atau image yang telah dibangunnya di dalam dunia media sosial. Berdasarkan penelitian dan observasi melalui dunia media sosial Instagram yang telah dilakukan, mahasiswa melakukan hal-hal tertentu demi mencapai representasi diri yang 
diinginkannya yakni melalui tiga jenis dari representasi diri sebagai basis pedoman atau standar perilaku presentasi diri oleh mahasiswa Jurusan Sosiologi Universitas Negeri Padang. Selebgram

Selebgram adalah istilah yang digunakan untuk memanggil selebriti atau orang-orang yang namanya terkenal melalui dunia sosial Instagram. Ada selebgram yang namanya terkenal karena hasil karyanya, kecerdasannya atau kemampuannya dalam melakukan hal tertentu yang kemudian hasil kerjanya mendapatkan apresiasi dari warganet atau netizen. Karena apresiasi tersebut kemudian nama-nama dari selebgram tersebut dapat dikenal banyak orang di dunia maya dan memberikan selebgram tersebut ketenaran. Namun ada juga orangorang yang namanya dikenal di dunia media sosial Instagram bukan karena karya atau kemapuan yang mereka miliki, akan tetapi mereka dikenal oleh warganet atau netizen karena tingkah laku yang kontroversial dan juga karena gosip atau drama yang beredar di dunia maya. Seperti yang dikatakan oleh salah satu informan peneliti yaitu OA sebagai berikut:

“...Menurut saya, selebgram itu merupakan orang yang terkenal di Instagram. Terkenal karena karya atau konten yang dia buat atau bisa juga terkenal karena gosip. Setiap orang yang terkenal di Instagram pasti bisa disebut sebagai selebgram..." (Wawancara, tanggal 12 Juni 2021).

Mahasiswa Jurusan Sosiologi Universitas Negeri Padang ada yang menjadi selebgram meski tidak seterkenal selebgram lainnya. Peneliti telah memilih narasumber yang menginginkan menjadi selebgram, dimana dirinya menjadi perhatian banyak orang di dalam dunia media sosial Instagram. Hal ini sesuai dengan pernyataan oleh HD yaitu:

“...Saya ingin menjadi selebgram karena bisa dikenal oleh banyak orang, lalu juga bisa untuk mencari uang di Instagram jika sudah menjadi selebgram. Senang rasanya jika nama saya dikenal oleh banyak orang di Instagram..." (Wawancara, tanggal 14 Juni 2021).

Berdasarkan tanggapan dari informan yang dikatakan kepada peneliti melalui wawancara, menunjukkan bahwa informan tersebut memiliki keinginan untuk menjadi seorang selebgram. Namun informan tidak memiliki karya atau kemampuan tertentu yang diunggahnya di akun media sosial Instagram miliknya. Informan memiliki caranya sendiri untuk membuat dirinya lebih dikenal di dunia media sosial Instagram dan mendapatkan followers agar jumlah followersnya bertambah. Cara yang digunakan oleh informan untuk mendapatkan followers lebih banyak banyak adalah dengan menggunakan tagar atau hashtag. Berikut pernyataa dari HD yaitu:

“...Saya menggunakan hashtag pada foto yang akan saya upload di feed Instagram. Soalnya foto tersebut bisa dilihat oleh orang yang tidak saling follow dengan Instagram milik saya. Seandainya orang tersebut like foto saya, nantinya foto tersebut akan muncul di explore akun Instagram milik orang yang saling follow dengannya. Dari sanalah followers atau like saya bisa bertambah secara perlahan..." (Wawancara, tanggal 14 Juni 2021).

Seseorang posting instastory Instagram dengan intensitas yang tinggi ingin eksis di dalam dunia maya, namun mereka memiliki cara lainnya agar tetap eksis di dunia media sosial Instagram yakni dengan cara mencari perhatian dari pengguna lainnya atau followers mereka. Untuk tetap eksis di dunia maya, mereka biasa menggunakan fitur question yang ada pada Instagram. Fitur question merupakan sebuah fitur yang ada dalam Instastory yang memungkinkan kita untuk bertanya kepada orang-orang yang melihat story yang telah dibuat 
dan nantinya kita dapat melihat reaksi atau jawaban yang mereka berikan atas pertanyaan yang telah dibuat dalam instastory.

Pada awalnya fitur question digunakan untuk mendapatkan informasi dari pengguna lain melalui story yang dibuat. Namun saat ini fitur question cenderung digunakan untuk membuat pertanyaan yang bertujuan hanya untuk mencari perhatian saja. Lalu, mahasiswa Jurusan Sosiologi Universitas Negeri Padang melakukan kegiatan menonton film di bioskop, kemudian akan membuat instastory berisikan foto dari tiket bioskop. Hal itu dilakukan untuk menunjukkan kepada jagad dunia maya bahwa ia telah menonton film yang sedang viral dan menjukkan bahwa ia tidak ketinggalan zaman. Orang yang berusaha menjadi seorang selebgram akan berusaha untuk mengikuti trend yang ada di jagad dunia maya. Karena dengan mengikuti trend yang ada maka akan membuat dirinya lebih eksis di dalam dunia media sosial Instagram mengingat tujuan dari orang tersebut adalah untuk menjadi terkenal di dalam dunia maya dan namanya dikenal oleh orang-orang di dalam dunia maya.

\section{Sosialita}

Menurut Subagio dalam (Roesma, 2013) mengatakan bahwa kata "socialite" diambil dari kata "social" dan "elite" yang dimulai dari keluarga kerajaan atau golongan bangsawan di Eropa yang selalu mendapatkan perlakuan khusus. Golongan pekerajaan dan bangsawan sejak masa dahulu selalu mendapatkan perlakuan yang istimewa, seperti tidak harus mengantri dan menunggu. Predikat sosialita didapatkan karena individu mempunyai jiwa sosial yang tinggi misalnya memiliki yayasan sosial dan aktif dalam kegiatan-kegiatan sosial.sedangkan setelah modernisasi, makna sosialita sudah mengalami pergeseran makna menjadi wanita kaya, baik wanita karier maupun istri-istri yang mempunyai suami seorang pengusaha yang suka arisan dengan nilai rupiah yang fantastis .

Namun di Indonesia makna sosialita berbeda jauh dengan makna sosialita yang sebenarnya. Masyarakat Indonesia memaknai sosialita sebagai sekumpulan orang kaya yang suka pamer barang-barang mewahnya dan juga gemar melakukan arisan. Mahasiswa Jurusan Sosiologi Universitas Negeri Padang juga memaknai sosialita sebagai orang yang memakai barang branded dari ujung kepala hingga kaki. Mahasiswa Jurusan Sosiologi Universitas Negeri Padang sering menemukan foto yang diunggah oleh sekelompok sosialita kemudian mahasiswa meniru apa yang dilakukan oleh kelompok-kelompok tersebut dengan tujuan agar tidak ketinggalan zaman atau trend. Namun ada mahasiswa yang memaksakan diri demi meniru gaya hidup yang dimiliki anggota kelompok sosialita tersebut. Disebut memaksakan diri karena sebenarnya mahasiswa tersebut dalam keluarga yang memiliki tingkat ekonomi menengah, namun mahasiswa tersebut malu sehingga memaksakan dirinya agar terlihat sebagai orang yang tergolong dalam tingkat ekonomi atas.

Mahasiswa Jurusan Sosiologi Universitas Negeri Padang mengunggah foto dirinya ketika sedang menggunakan barang yang memiliki nilai prestise seperti barang dengan merk ternama. Barang-barang tersebut seperti iphone, sendal merk Elizabeth, jam tangan merk Daniel Wellington atau Alexandre Christie, tas merk Charles and Keith, YSL, Channel dan lain-lain. Mahasiswa memaksakan dirinya untuk menjalani gaya hidup yang menyusahkan diri seperti itu karena mahasiswa terlalu mendahulukan gengsi dan mengesampingkan hal lainnya. Mahasiswa menghabiskan uangnya hanya untuk memenuhi gaya hidup yang mendahulukan gengsi itu dengan cara membeli barang-barang yang memiliki nilai prestise tinggi.

Alasan mahasiswa menjalani gaya hidup layaknya seorang sosialita adalah ingin terlihat lebih kaya, lebih keren, lebih kekinian, lebih hits dari yang lainnya. Cara yang 
dilakukan untuk terlihat lebih keren dan lebih hits dari yang lainnya adalah dengan cara menggunakan barang-barang yang memiliki nilai prestise tinggi seperti gadget dan barangbarang branded lainnya. Hal ini sesuai dengan pernyataan oleh PIS yaitu:

“...Saya menggunakan iphone karena ada kebanggan tersendiri, merasa lebih unggul daripada teman yang lainnya. Contohnya saja pada saat pergi nongkrong ke cafe teman-teman saya suka meminjam hp saya untuk membuat instastory atau foto-foto. Soalnya jika membuat instastory di iphone lebih bagus daripada menggunakan android...” (Wawancara, tanggal 16 Juni 2021).

Selain PIS Peneliti juga mewawancarai informan lain dengan inisial MA berikut pernyataannya:

“...Saya menggunakan iphone agar tidak ketinggalan dari teman saya yang lain, karena hampir seluruh teman dekat saya menggunakan iphone. Jadi agar saya bisa memakai smartphone iphone saya membelinya bekas. Kalau menggunakan samrtphone iphone saya merasa bangga saat membuat instastory pada Instagram.." (Wawancara, tanggal 17 Juni 2021).

Dari wawancara yang dilakukan peneliti dengan informan tersebut, menunjukkan bahwa mahasiswa yang menjalani gaya hidup layaknya seorang sosialita lebih mementingkan prestise yang didapatkan dari sebuah barang daripada nilai guna yang didaptkan dari barang tersebut. Mahasiswa tidak mengetahui betul fitur apa yang diberikan dan didapatkan dari sebuah iphone. Tapi mahasiswa membeli iphone karena semata-mata brandnya saja karena iphone memiliki harga yang terbilang mahal untuk sebuah telpon genggam. Karena itu iphone mampu memberikan prestise kepada pemiliknya. Hal yang sama juga terjadi dengan fashion yang dikenakan. Mahasiswa Jurusan Sosiologi Universitas Negeri Padang kerap menggunakan fashion dengan brand ternama di badannya. Hal ini sesuai dengan pernyataan oleh PIS yaitu:

“...Saya suka memakai barang-barang bermerk karena bagus saat dipakai, lalu supaya tidak ketinggalan zaman. Makanya saya memakai barang yang bermerk terkenal di kalangan anak muda...” (Wawancara, tanggal 16 Juni 2021).

Dalam kalangan mahasiswa tumbuh sebuah pemikiran yakni ketika mahasiswa tidak mengenakan suatu barang yang branded maka akan dianggap tidak gaul atau hits. Mahasiswa seakan-akan mendapatkan kebanggan tersendiri ketika mengenakan barang branded, entah itu berupa tas, sendal atau sepatu. Selain menunjukkan barang-barang branded yang dimiliki kemudian mengunggahnya ke media sosial Instagram, mahasiswa yang memiliki kebiasaan seperti layaknya sosialita ini memiliki kebiasaan lainnya. Kebiasaan lain itu adalah pergi ke tempat wisata atau travelling maka akan diikuti dengan unggahan foto-fotonya ketika berwisata. Intensitas dalam mengunggah foto dan instastory mengingat jauh lebih tinggi dari sebelumnya. Hal ini sesuai berdasarkan pernyataan oleh BNP yaitu:

“...Saya pernah pergi liburan bersama dengan teman kuliah menggunakan mobil rental, tetapi saya meminta uang lebih kepada orang tua saya dengan alasan untuk keperluan penelitian. Soalnya kalau tidak seperti itu uang jajan saya perminggu saja tidak cukup. Lalu saya tidak lupa untuk spam instastory di Instagram jika pergi liburan..." (Wawancara, tanggal 18 Juni 2021).

Berdasarkan wawancara tersebut menunjukkan bahwa ada sesuatu di balik apa yang diunggahnya di media sosial Instagram. Mahasiswa berbohong kepada orang tuanya dan 
meminta sejumlah uang. Hal itu dilakukan untk memenui hasratnya untuk berlibur bersama teman-temannya. Mahasiswa mau melakukan segala upaya cara untuk mewujudkan keinginannya seperti seorang sosialita dan hal itu seakan menjadi gaya hidup dari mahasiswa untuk berfoya-foya dan membeli barang-barang branded agar terlihat status sosialnya lebih tinggi dari yang sebenarnya.

\section{Motivator,}

Motivator adalah meniru gaya seorang motivator. Bukan menirukan seorang motivator tertentu atau impersonate tetapi orang tersebut berlagak bijak dan kerap mengeluarkan katakata bijak. Hal tersebut seakan menjadi trend dalam dunia media sosial. Mengikuti trend yang ada mahasiswa Jurusan Sosiologi Universitas Negeri Padang juga melakukannya melalui akun media sosial yang dimilikinya. Biasanya seseorang akan mengunggah sebuah foto dengan gambar yang dipilihnya kemudian menuliskan kata-kata yang bijak dalam foto tersebut. Quotes yang sering dibuat dan disebarkan di dunia sosial media Instagram oleh mahasiswa sebagian besar mengenai kisah cinta, pengalaman hidup atau pengalaman sosial. Tentu saja quotes tersebut memiliki pesan yakni untuk menyemangati pembacanya agar menjadi orang yang lebih tegar dalam menghadapi permasalahan yang dihadapinya. Berikut pernyataan dari informan MA:

“...Saya sering posting seperti kalimat yang ada di quotes sangat mewakili apa yang saya rasakan. Tapi yang membuat diri sendiri semangat dan sekalian biar followers saya juga membacanya mana tau jadi ikutan terbantu..." (Wawancara, tanggal 20 Juni 2021).

Terkadang mahasiswa juga merasa bahwa quotes yang diberikan pada gambar tersebut juga mewakili perasaan mereka, mewakili keresahan mereka ketika menghadapi suatu permasalahan. Namun secara tak sadar hal yang dilakukannya itu juga terkadang justru malah mengekspos masalahnya kepada followersnya di dunia media sosial Instagram. Selain mengunggah atau repost kata-kata bijak mengenai kisah cinta, persahabatan atau persoalan hidup lainnya, kini ada trend baru yang muncul di dunia media sosial Instagram. Trend tersebut adalah me-repost kata-kata bijak yang diambil berdasarkan politik. Mahasiswa kerap mengunggah ulang foto-foto milik akun lain yang diikutinya di Instagram. Namun mahasiswa itu sendiri tidak benar-benar mengetahui bagaimana kata-kata yang diunggahnya tersebut.

Berdasarkan ketiga representasi diri yang ditunjukkan oleh mahasiswa untuk melakukan representasi diri demi dirinya eksis di dunia maya. Informan tersebut tidak benarbenar langsung melejit dan dikenal oleh orang-orang pengguna media sosial Instagram. Nama informan hanya dikenal sebatas oleh followersnya saja dan tidak eksis diantara penguna lain yang tidak mem-follownya. Setelah melakukan representasi diri di dunia maya dengan merepresentasi diri seperti selebgram, sosialita dan motivator tidak memberikan dampak yang kentara pada dirinya. Hal itu dikarenakan tidak ada suatu ciri atau image tertentu yang menjadi ciri khas yang dapat membuat orang tersebut terkenal. Yang dilakukan informan hanyalah sebatas meniru apa yang dilakukan oleh orang lain dan di mata pengguna Instagram lainnya, hal tersebut bukanlah hal yang spesial sehingga mengakibatkan nama informan tidak melejit dan terkenal.

\section{Pembahasan}

Analisis Representasi Diri Pada Media Sosial Instagram Dalam Tinjauan Teori Dramaturgi Oleh Erving Goffman 
Representasi diri kerap dilakukan oleh mahasiswa dan mahasiswi Jurusan Sosiologi Universitas Negeri Padang pada media sosial yang dimilikinya. Media sosial yang paling sering digunakan untuk melakukan representasi dirinya yakni media sosial Instagram. Mahasiswa memiliki kebebasan penuh untuk membangun citra yang mahasiswa ingin bangun di dalam benak orang lain atau followersnya di dunia maya. Ada mahasiswa yang merepresentasikan dirinya apa adanya, namun ada juga mahasiswa yang merepresentasikan dirinya tidak sesuai dengan apa yang dimilikinya. Hal tersebut dilakukan oleh mahasiswa agar status sosialnya terlihat lebih tinggi dari status sosial yang sesunggunya, harapannya dengan memiliki status sosial yang lebih tinggi mahasiswa akan mendapatkan sebuah pengakuan dari lingkungan di sekitarnya atau lingkungan pertemannya. Penelitian ini berfokus pada perilaku mahasiswa yang merepresentasikan dirinya berbeda antara panggung depan (Front Stage) dan panggung belakang (Back Stage).

Seperti yang sudah dipaparkan di atas oleh peneliti, ada tiga jenis representasi diri yang dilakukan oleh mahasiswa agar dirinya tampak memiliki status sosial yang lebih tinggi dari status sosial yang sesungguhnya melalui dunia maya. Tiga jenis representasi diri tersebut yakni selebgram, sosialita, dan motivator sebagai basis pedoman mahasiswa melakukan representasi dirinya di Instagram. Tiga jenis representasi diri tersebut memiliki ciri-ciri yang berbeda antara satu dengan lainnya.

Dalam penelitian ini, peneliti menggunakan teori dramaturgi milik Erving Goffman untuk mengkaji fenomena yang terjadi di lapangan. Erving Goffman menjelaskan bahwa kehidupan sosial manusia dianggap seperti serangkaian pertunjukkan drama yang mirip dengan pertunjukan teater di panggung. Sebagaimana panggung teater, dalam teori dramaturgi milik Erving Goffman terdapat dua panggung yakni panggung depan (front stage) dan panggung belakang (back stage). Panggung depan adalah tempat dimana seseorang memainkan perannya di hadapan para penontonnya. Sedangkan panggung belakang adalah tempat dimana seseorang mempersiapkan segala hal yang dapat melengkapi keberhasilan dalam memainkan perannya di panggung depan.

Mengenai apa yang dikemukakan Erving Goffman dalam teori dramaturgi miliknya bahwa seseorang cenderung menyembunyikan beberapa hal tertentu ketika sedang tampil di panggung depan. Begitu juga dengan yang ditemukan oleh peneliti di lapangan. Peneliti menemukan bahwa mahasiswa menyembunyikan beberapa hal atau bahkan beberapa sifat tertentu dari panggung depannya yakni dunia media sosial Instagram. Mahasiswa cenderung hanya memperlihatkan versi baik dari dirinya sesuai dengan peran yang dimainkannya.

Dalam panggung depan, Erving Goffman mengemukakan bahwa terdapat dua bagian dalam panggung depan yakni personal front dan setting. Yang dimaksud dengan personal front adalah segala hal yang dapat membantu memperkuat karakter yang diperankan aktor di panggung depan. Hal-hal tersebut meliputi alat-alat atau perlengkapan yang dibawa oleh aktor, bahasa verbal, bahasa tubuh, serta kenampakan fisik dari sang aktor seperti bentuk tubuh, ras, dan usia. Sementara setting adalah latar yang dapat membantu aktor memainkan perannya di depan khalayak penonton. Seperti misalnya, seorang selebgram yang berada di tempat hits untuk melakukan endorsement, seorang sosialita yang sedang makan di restoran mewah, dll.

Pada panggung depan ini, aktor berusaha melakukan pengelolaan kesan atau Erving Goffman menyebutnya dengan impression management. Impression Management adalah upaya menumbuhkan kesan pada benak orang lain sesuai dengan keinginan sang aktor. Begitu juga yang dilakukan oleh mahasiswa Jurusan Sosiologi Universitas Negeri Padang, mahasiswa berusaha melakukan impression management pada followersnya melalui dunia 
media sosial Instagram. Mahasiswa melakukan representasi diri melalui dunia maya agar orang lain melihat dirinya sesuai dengan apa yang direpresentasikannya. Dalam membangun representasi diri melalui dunia maya, mahasiswa cenderung menutupi sifat atau karakter asli dari dirinya agar orang lain hanya melihat versi baik dari dirinya saja demi menumbuhkan representasi yang sesuai dengan keinginannya. Bahkan, mahasiswa sampai melakukan hal tertentu demi membangun kesan yang diinginkannya. Mahasiswa menyembunyikan hal-hal tersebut di panggung belakangnya agar tak dilihat oleh khalayak penonton.

Dalam penelitian ini, peneliti menemukan bahwa panggung belakang mahasiswa Jurusan Sosiologi Universitas Negeri Padang berbeda jauh dengan apa yang ditampilkannya di panggung depan. Selain itu peneliti juga menemukan beberapa hal yang mengejutkan yang dilakukan oleh mahasiswa di panggung belakangnya. Hal tersebut sudah tentu dilakukan mahasiswa untuk menunjang peran dan penampilannya di panggung depan miliknya. Seperti yang telah diuraikan pada temuan di atas, peneliti menemukan bahwa panggung belakang dari mahasiswa menunjukkan hal yang berbeda 180 derajat dengan apa yang ditampilkannya di dunia maya. Mahasiswa melakukan berbagai hal demi menunjang penampilannya di panggung depan. Hal tersebut sesuai dengan apa yang dikemukakan oleh Erving Goffman mengenai panggung belakang, yakni panggung belakang adalah tempat dimana aktor berlatih atau melakukan persiapan untuk menyempurnakan peran yang akan dimainkannya di panggung depan.

Mahasiswa rela mengeluarkan sejumlah uang untuk menggunakan jasa penambah followers. Hal itu dilakukan mahasiswa demi mendukung peran yang dimainkannya yakni sebagai selebgram di dunia maya. Hal tersebut sesuai dengan yang diungkapkan oleh Erving Goffman bahwa tujuan dari pementasan adalah untuk melakukan impression management. Impression management adalah pembangunan kesan ke dalam benak khalayak penonton sesuai dengan peran yang ditampilkan aktor di panggung depannya. Mahasiswa ingin menciptakan kesan pada orang lain sesuai dengan citra yang telah dibangunnya melalui dunia maya. Seperti yang dilakukan oleh mahasiswa mengunggah foto ketika sedang makan di restoran mewah, maka sebenarnya mahasiswa ingin membangun citra pada benak followersnya bahwa mahasiswa tersebut tergolong orang kaya, namun pada kenyataannya mahasiswa tersebut belum tentu sekaya seperti yang dicitrakannya di dunia maya.

\section{Kesimpulan}

Dalam penelitian ini, peneliti menemukan bahwa mahasiswa demi mencapai tujuannya di media sosial Instagram melakukan representasi diri. Ada tiga jenis representasi diri yang peneliti temukan yakni selebgram, sosialita dan motivator sebagai basis pedoman untuk melakukan representasi diri. Mahasiswa Jurusan Sosiologi Universitas Negeri Padang merepresentasikan dirinya seperti seorang selebgram dengan harapan bahwa dirinya dapat eksis di dunia media sosial Instagram sekaligus di dunia nyata pergaulannya. Kemudian ada mahasiswa yang merepresentasikan dirinya sebagai seorang sosialita yang memiliki gaya hidup mewah dan glamour. Merepresentasikan dirinya dengan gaya hiduo yang sangat konsumtif agar terlihat bahwa dirinya dianggap tergolong sebagai orang kaya padahal kenyataan yang ada tidak seperti itu dan yang terakhir yakni mahasiswa yang merepresentasikan dirinya seperti seorang motivator. Mahasiswa sering kali mengunggah foto yang berisi kalimat-kalimat bijak untuk menyemangati followersnya ketika menghadap suatu permasalahan. Mahasiswa merepresentasikan seperti itu karena menginginkan sebuah pengakuan dari lingkungannya dan agar status sosialnya meningkat dari status asli miliknya. 


\section{Daftar Pustaka}

Alwisol. (2010). Psikologi Kepribadian. Malang: UMM Press.

Arlian, P. D. (2015). Analisis Perilaku Pencarian Informasi Mengenai Breastfeeding Pada Ibu Net Generation. Megister Media Dan Komunikasi Universitas Airlangga.

Atmoko, D. B. (2012). Instagram Handbook. Jakarta: Remaja Rosdakarya.

Gautama, M. I. (2017). Pencitraan Melalui Media Daring: Analisis Framing Situs Gubernur Sumatera Barat. Jurnal Prosiding Konferensi Nasional Komunikasi, 01.

Lidwina, A. (2021). Instagram, Media Sosial Paling Serius Digunakan.

Nasrullah, R. (2015). Media Sosial (Perspektif Komunikasi, Budaya dan Sosioteknologi). Jakarta: Rajawali Press.

Poloma, M. (2013). Sosiologi Kontemporer (Tim Penerj). Jakarta: PT Raja Grafindo Persada.

Roesma, J. N. (2013). Kocok! Uncut: The untold stories of arisan ladies and socialites. Jakarta: PT Gramedia Pustaka Utama.

Sugihartati, R. (2014). Perkembangan Masyarakat Informasi dan Teori Sosial Kontemporer. Jakarta: Kencana Prenada Media Group. 